\title{
Independent Policymaking and Presidential Power: A Constitutional Analysis
}

Peter M. Shane*

Legal historians of the late twentieth century will undoubtedly mark the Reagan years as a kind of renaissance for separation of powers law. The Reagan Justice Department, whether under William French Smith or Edwin Meese III, was unusually creative, if not unusually successful, in invoking separation of powers rhetoric to defend unilateral presidential initiatives and to challenge those practices it disfavored of the other branches. ${ }^{1}$ In part as a result of the Department's efforts, federal courts have been deciding separation of powers disputes at an accelerated pace, ${ }^{2}$ Congress has renewed its attention to separation of powers principles, ${ }^{3}$ and legal

* Professor of Law, University of Iowa; A.B. 1974, Harvard; J.D. 1977, Yale. I received helpful comments on an earlier draft of this paper from Professors David Kaye, Greg Williams, and Lakshman Guruswamy. I benefitted also from the research assistance of Iowa law students Pat Sullivan and John Carver and, most especially, Diane Marchik.

1. See generally Miller, From Compromise to Confrontation: Separation of Powers in the Reagan Era, 57 GEO. WASH. L. REv. - - (1989); Shane, Federal Policy Making By Consent Decree: An Analysis of Agency and Judicial Discretion, 1987 U. CHI. Legal F. 241, 278 n.136.

2. Miller, supra note 1 , at -

3. Examples include the House Judiciary Committee investigation of executive privilege claims against Congress that triggered the dispute culminating in Morrison $v$. Olson, 108 S. Ct. 2597 (1988), see House Comm. ON THE Judiciary, INVEstigation of The Role of the Department of Justice in the Withholding of Environmental ProtecTION AGENCY Documents From Congress in 1982-83, H.R. Rep. No. 435, 99th Cong., Ist Sess. (1985) (four vols.); the Iran-Contra investigation, S. REP. No. 216, 100th Cong., lst Sess. (1987); and the consideration of various proposals to amend the War Powers Resolution, see Morrison, New Phase for War Powers Debate, NaT'L J., June 25, 1988, at 1690 . 
academics have generated an exciting new literature on a host of separation of powers problems.

The Reagan administration's efforts in the separation of powers area stand in tension, however, with another hallmark of Reagan constitutionalism, namely, the call to constitutional originalism. That is because originalism provides only the weakest possible support for at least some of the separation of powers positions that his Justice Department urged most forcefully. The irony of the Reagan administration's legal legacy may be the degree to which its efforts in the separation of powers arena may ultimately be regarded as undermining its campaign for originalism. By ascribing such importance to issues of government structure, the administration lent impetus, however inadvertently, to an emerging "values-oriented" separation of powers literature. This "modernist" literature, on some issues at least, provides more interesting arguments than did the Justice Department for the Reagan administration's proffered conclusions.

This article seeks to make the case for at least the occasional weightiness of values-oriented separation of powers law by exploring an alleged constitutional conflict perceived by the Reagan administration (and by various scholars). It is a supposed conflict between the President's constitutionally vested authority as head of the executive branch and Congress's creation of various "independent" policymakers, whose administrative functions are not susceptible to plenary presidential control. One such administrator is the independent counsel created by the Ethics in Government Act, ${ }^{4}$ popularly known as the "special prosecutor law." Others include the commissioners of the various "independent agencies," each of whom is statutorily protected against "at will" presidential removal.

I will argue two theses. The first is that the only weighty arguments against congressional decisions to authorize independent administrators are modernist. The second is that even the modernist attack on independent policymaking is unpersuasive. Congressional decisions to vest authority in independent administrators do downplay one value embodied in our constitutional structure, that is, the value of centralized accountability. Such decisions, however, also help to promote two other, equally central constitutional commitments: the commitment to legislative primacy in domestic policymaking, and the commitment to a general diffusion of government power.

Part I of this article reviews the independent counsel dispute, a

4. Ethics in Government Act of 1978, 28 U.S.C. $\S \S 591-599$ (1982 \& Supp. IV 1986). 
dispute as to which an originalist interpretation of the Constitution-as the Reagan administration understood originalism-is possible. Part I argues that formalist interpretations of the Constitution, including originalism, fully sustain both the creation of independent counsel and the Supreme Court's recent lopsided vote in Morrison v. Olson. ${ }^{5}$

Part II of this article considers the problem of independent civil administrators, an issue on which originalism again supports Congress, but may not appear as sensible an interpretive strategy. Part II rehearses what might be called a modernist values-oriented attack on independent agencies, and musters a modernist values-oriented defense. Part II argues that the insulation of civil administrators from plenary presidential control is constitutional, even though the values-oriented attack on such adminstrators is the most intellectually important challenge to be met.

Part III revisits Morrison $v$. Olson to consider two issues: first, whether a modernist case was available against independent counsel and, second, if so, whether such arguments should count when a persuasive textualist or originalist case points in a different direction.

\section{Morrison v. Olson: An Easy Formalist Case?}

In Morrison v. Olson the Supreme Court upheld, in a seven-to-one vote, the constitutionality of a limited class of judicially appointed prosecutors called "independent counsel," who are subject to removal by the Attorney General only for statutorily described cause. These prosecutors are appointed, on petition of the Attorney General, in cases involving alleged serious federal offenses by a designated class of high-level executive branch and campaign officials. ${ }^{6}$

There was once a time when commentators on such a case might simply proceed to proffer their reasoning under the Constitution for one or another result. No more. Jurisprudential debates over the last fifteen years-debates in which the Reagan Justice Department aggressively engaged-have made constitutionalists profoundly aware of the controversy surrounding not only particular constitutional arguments, but the choice among different ways of arguing about the Constitution. Before analyzing a constitutional dispute, it is now common to specify the rules by which one is playing-what kinds of arguments count and for how much.

A variety of constitutionalists, including former Attorney General Meese, adhere at least sometimes to some brand of what is often called formalism. By formalism, I mean to include all varieties of interpretive theory that purport to yield reasonably determinate answers to legal disputes by relying on a fairly well-defined set of legal

5. 108 S. Ct. 2597 (1988).

6. 28 U.S.C. $\$ 591$ (a), (b) (1982 \& Supp. IV 1986). 
materials and not consciously attending to any broad normative theory about what is at stake in a particular controversy. From a formalist point of view, the majority in Morrison was clearly correct.

\section{A. Textualism}

One brand of formalism is textualism, the theory that, in at least some cases, one can derive sensible answers to constitutional questions from conventional readings of constitutional language. ${ }^{7}$ Imagine, for example, an English-fluent legal scholar from the planet Mars-many, I suspect, believe that textualists must be from Mars ${ }^{8}$ - who is given a copy of the Constitution and told to adjudicate Morrison v. Olson. Our Martian is told that independent counsels may be unconstitutional for three reasons: first, they are appointed by courts; second, their removability by the President is impermissibly limited; third, they improperly usurp presidential authority and improperly aggrandize judicial authority over criminal prosecution.

The textualist is likely to come fairly readily to at least the presumptive conclusion that independent counsels are constitutional. On the appointment issue, the Constitution provides: "Congress may by Law vest the Appointment of such inferior Officers, as they think proper, in the President alone, in the Courts of Law, or in the Heads of Departments." 9 The textualist may have some question as to the scope of the phrase, "inferior officer." Yet, because an independent counsel is apparently a temporary appointee for the investigation of criminal charges relating to a single individual, such an official surely has the feel of "inferior-ness." The counsel is not in charge of very much or for very long. ${ }^{10}$ The textualist knows there are officials such as cabinet secretaries and agency heads who are responsible for a broad range of policymaking over a substantial subject matter jurisdiction. These officials would appear most glaringly to be "superior" or "principal" officers, not subject to the above-quoted clause.

As for removals, the text provides only for congressional removal of government officers, namely, by impeachment. ${ }^{11}$ The textualist

7. For a more extended discussion of the limits of plausible textualism, see generally Shane, Conventionalism in Constitutional Interpretation and the Place of Administrative Agencies, 36 AM. U.L. REv. 573 (1987).

8. Stephen Carter makes a similar remark concerning originalism: "Among constitutional theorists, originalism holds roughly the status of Lysenkoism among geneticists: a silly idea no longer worth the energy required to refute it." Carter, Comment: The Independent Counsel Mess, 102 HaRv. L. Rev. 105, 118 (1988).

9. U.S. ConsT. art. II, $\S 2, \mathrm{cl} .2$.

10. Morrison, $108 \mathrm{~S}$. Ct. at 2608-09.

11. U.S. Const. art. I, $\S 2, \mathrm{cl} .5$ ("The House of Representatives . . . shall have the sole Power of Impeachment."); id. § 3, cls. 6-7 ("The Senate shall have the sole Power to try all Impeachments .... Judgment in Cases of Impeachment shall not extend further 
may be uncertain whether the implication of the impeachment power is that Congress is barred from involving itself in removals through any other mechanism. ${ }^{12}$ That question, however, is beside the point in Morrison. The constitutional challenge to independent counsels is not that Congress has aggrandized its removal power, but rather that it has limited the President's.

Article II, however, does not make any express reference to presidential removal power. Much less does it expressly require that the President have plenary removal power over any official. ${ }^{13}$ A textualist might think that Congress may give the President plenary removal authority over an inferior officer if such a delegation of power appears appropriate to the functioning of that officer. The inference arises from Congress's express power " $[t] 0$ make all Laws which shall be necessary and proper for carrying into Execution ... all ... Powers vested by this Constitution in the Government of the United States, or in any Department or Officer thereof."14 Congress might well consider that the implementation of an administrative function might be most effective if undertaken by an official subject to presidential supervision.

By the same token, however, a Congress that thinks it "necessary and proper" to limit an inferior officer's vulnerability to presidential removal power would also appear textually authorized to make that structural choice. The only limit on Congress's preference in that regard, a textualist would observe, is that the President could not be deprived of at least such removal power as is absolutely necessary to vindicate some express power he enjoys under article II.

As the textualist canvasses article II to find a presidential power that might limit Congress's choices regarding presidential removal authority, only one is likely to emerge as a candidate. The President is to "take Care that the Laws be faithfully executed."15 A possible inference from this clause is that the President must be able to dismiss any administrative officer of the government who is not faithfully executing the laws; such would be the most efficient means for fulfilling the President's express obligation. But, our textualist notes, the Attorney General may dismiss an independent counsel "only for good cause, physical disability, mental incapacity, or any other condition that substantially impairs the performance of such

than to removal from Office and disqualification to hold and enjoy any Office of honor, Trust or Profit . . . ."); id. art. II, $\S 4$ (Civil officers "shall be removed from Office on Impeachment for, and Conviction of, Treason, Bribery, or other high Crimes and Misdemeanors.").

12. Bowsher v. Synar, 478 U.S. 714, 727-34 (1986) (holding that removability of Comptroller General by Congress other than through impeachment precludes delegation to Comptroller General of significant authority over executive branch); Myers v. United States, 272 U.S. 52, 176 (1926) (invalidating statutory requirement that President obtain Senate approval for the removal of an executive officer).

13. On the constitutional uncertainties surrounding presidential removal power, see Entin, The Removal Power and the Federal Deficit: Form, Substance, and Administrative Independence, 75 KY. L.J. 699, $712-27$ (1986).

14. U.S. Const. art. I, $\S 8, \mathrm{cl} .18$.

15. Id. art. II, \& 3 . 
independent counsel's duties." 16 Our textualist will probably consider the likelihood that "good cause" encompasses unlawfulness. Because the Attorney General may dismiss an independent counsel who is acting unlawfully, and because the President has plenary control over the Attorney General, the President's authority over removals of independent counsels seems sufficient to protect his constitutionally vested law enforcement function. ${ }^{17}$

On the third argument-that independent counsels impermissibly usurp presidential power or impermissibly aggrandize judicial power-there is less text to go on. The President may, under the faithful execution clause just discussed, have inherent power to assure that criminal prosecutors are themselves acting lawfully. Nothing in the text, however, says that the President must control criminal prosecution more generally. The one puzzle for the textualist is the existence of a clause vesting "executive Power" in the President, ${ }^{18}$ which raises the question as to whether criminal prosecution is encompassed by this phrase. Even so, however, Congress has the power to make laws "necessary and proper for carrying into Execution ... all . . Powers" vested in the government, ${ }^{19}$ necessarily including executive powers. Thus, even if criminal prosecution were an "executive" power-and the textualist has no easy answers here-it would not be clear why Congress could not structure the counsel's powers as it has.

As for the courts, a textualist cannot regard it as an undue aggrandizement of judicial power for judges to appoint an official that article II expressly permits them to appoint. ${ }^{20}$ Moreover, it hardly seems usurpatious for the court to be given certain narrowly circumscribed duties with respect to defining the prosecutor's jurisdiction and monitoring the prosecutor's activities, especially when vesting those duties in a court is critical for accomplishing Congress's objective of preserving the prosecutor's relative policy independence from the executive. ${ }^{21}$ The textualist recognizes that some grants of judicial power to control an inferior official might compromise the ability of the judiciary to fulfill its other expressly vested powers, and that would be a problem. Yet, no obvious reason exists why the limited judicial powers regarding independent counsels should compromise the courts' expressly vested power to decide "cases" and "controversies."22

The Martian I have described has come amazingly close to

16. 28 U.S.C. $\S 596(a)(1)$ (1982).

17. Morrison, $108 \mathrm{~S}$. Ct. at 2619.

18. U.S. Const. art. II, $\S 1$, cl. 1 .

19. Id. art. I, $\S 8, \mathrm{cl} .18$ (emphasis added).

20. Id. art II, § 2, cl. 2; Morrison, 108 S. Ct. at 2612.

21. See id. at 2613-15.

22. Id.; Ex parte Siebold, 100 U.S. (10 Otto) 371 (1890) (upholding the appointment 
describing the majority's opinion in Morrison v. Olson. The Court's sole dissenter, Justice Scalia, laments, "The Court devotes most of its attention to such relatively technical details as the Appointments Clause and the removal power . . .,"23 but the fact is that, from a textualist standpoint, these technical details overwhelmingly support Congress.

\section{B. Originalism}

A different kind of formalist might object that textualism is the wrong interpretive method because the constitutional language expresses only imperfectly what really should matter, namely, the expectations of the founding generation regarding the precise meaning of their document-what is often called "original intent." 24 As it turns out, however, the "originalist" and the "textualist" analyses converge.

Former Judge Robert Bork has succinctly expressed the core assertion underlying originalism: " $[\mathrm{T}]$ he ultimate source of constitutional legitimacy is compliance with the intentions of those who framed and ratified our Constitution."25 Originalism is the species of formalism-that is, history partly expressed in text-to which the Reagan administration swore allegiance:

Where the language of the Constitution is specific, it must be obeyed. Where there is a demonstrable consensus among the framers and ratifiers as to a principle stated or implied by the Constitution, it should be followed. Where there is ambiguity as to the precise meaning or reach of [a] constitutional provision, it should be interpreted and applied in a manner so as to at least not contradict the text of the Constitution itself. ${ }^{26}$

An originalist who objects to the textualist resolution of Morrison would have to argue that an historical inquiry into the Constitution reveals that criminal prosecution was understood to be an "inherently" executive function vested in the President by article II, and thus a power, his exercise of which must include plenary policy discretion bounded only by the Constitution and by properly enacted criminal law.

Frequent and familiar objections have been made to constitutional originalism as an interpretive strategy. ${ }^{27}$ One must, however,

of judges as supervisors of congressional elections as not incongruous with article III duties).

23. Morrison, 108 S. Ct. at 2625 (Scalia, J., dissenting).

24. For a distillation of the Reagan administration's official thinking on originalism (and a bibliography of relevant scholarly works), see U.S. DEPARTMENT OF JUSTICE OFfice of Legal Policy, Original Meaning Jurisprudence: A Sourcebook (1987). A useful "scorecard" for the current debate is Farber, The Originalism Debate: A Guide for the Perplexed, 49 OHio ST. L.J. 1085 (1989).

25. Barnes v. Kline, 759 F.2d 21, 56 (D.C. Cir. 1985) (Bork, J., dissenting), vacated sub nom. Burke v. Barnes, 479 U.S. 361 (1987).

26. Address by Attorney General Edwin Meese III Before the D.C. Chapter of the Federalist Society Lawyers Division (Nov. 15, 1985), reprinted in U.S. DEPaRTMENT of JUSTICE OfFice of Legal Policy, supra note 24, at 96.

27. See, e.g., Brest, The Misconceived Quest for Original L'nderstanding, 60 B.U.L. REv. 204 (1980). 
admit this: If originalism is a strategy with any promise ever, then it might well be employed to ascertain the merits of the argument against independent counsels, because the originalist inquiry into the constitutional status of a criminal prosecutor is at least free from anachronism. It is not odd to inquire into the eighteenth century conception of criminal prosecution as it would be odd to ask whether "the Framers" intended the Federal Communications Commission to be an executive agency. The founding generation was well acquainted with criminal prosecution. Whether criminal prosecution was conventionally understood in the late eighteenth century as inherently executive in a government structured in the manner of our national government is a coherent question.

There is no definitive federal debate on the subject. The Judiciary Act of 1789 originally provided for the judicial appointment of district attorneys, which would strongly belie the argument from original understanding. ${ }^{28}$ Yet, the provision was changed by Congress, which authorized the President to appoint United States attorneys. ${ }^{29}$ Such a change would support the originalist case against independent counsels, except that there is no evidence that the change was perceived as a matter of "constitutional compulsion," rather than of policy choice. ${ }^{30}$ Indeed, the early functioning of United States attorneys fails to substantiate any expectation that the President would provide some unifying supervision: "Prosecution was decentralized during the federalist period, and it was conducted by district attorneys who were private practitioners employed by the United States on a fee-for-services basis." 31

One other piece of federal evidence is inconsistent with the originalist attack on independent counsels, but may not be strongly relevant. Federal courts have always been regarded as having the power to appoint prosecutors to bring criminal contempt actions. ${ }^{32}$ This practice is an obvious breach of executive control over prosecution, but originalists might regard it as a limited exception to a general rule of executive control that was carved out for the sole purpose of preserving judicial independence in the protection of judicial process.

If federal evidence alone is inconclusive, however, other evidence

28. In re Sealed Case, 838 F.2d 476, 533 n.41 (D.C. Cir.) (R.B. Ginsburg, J., dissenting), rev'd sub nom. Morrison v. Olson, 108 S. Ct. 2597 (1988).

29. Id. at 492.

30. Id. at 533 n.41.

31. Id. at 526-27 (citation omitted). It was not until 1831 that an Attorney General opined that the President could lawfully order the discontinuation of a prosecution-in that particular instance, an in rem proceeding against the property of a friendly foreign power. The Jewels of the Princess Orange, 2 Op. Att'y Gen. 483, 487 (1831).

32. Young v. United States ex rel. Vuitton et Fils S.A., 481 U.S. 787, 793 (1987) (observing that "inherent" judicial power to appoint private lawyers to prosecute contempt actions is "long settled"). 
regarding the founding generation's likely perceptions regarding criminal prosecution and its constitutional status is both consistent and telling. States had prosecutors, and state practice in the late eighteenth century most strongly suggests that there was no late eighteenth century expectation that criminal prosecution was an inherently executive function, to be conducted solely by gubernatorial appointees and under exclusive executive supervision. Indeed, there appear at least five states in which clear evidence belies any such understanding.

In 1787, Virginia was operating under its Constitution of 1776, under which "the executive powers of government" were vested in a governor. ${ }^{33}$ That Constitution provided, however, that the Attorney General would be appointed by the "two Houses of Assembly ... by joint ballot."34 The North Carolina Constitution of $1776^{35}$ and the South Carolina Constitution of $1778,{ }^{36}$ also operational in 1787 , likewise provided for their respective legislatures to appoint each state's Attorney General, although each Constitution vested the "executive power" in the governor. ${ }^{37}$ Moreover, a North Carolina statute of 1777 empowered county courts to appoint additional prosecuting attorneys. ${ }^{38}$

In 1784 , Connecticut provided by statute for the appointment of state's attorneys by the county courts. ${ }^{39}$ This practice persisted until at least 1854,40 notwithstanding the adoption of a new Constitution in 1818 to replace the Charter of 1662 as the state's

33. VA. Const. of 1776 , reprinted in $10 \mathrm{~W}$. Swindler, Sources ANd Documents of UnITEd States Constirutions 53 (1979) ("A Governor . . . shall be chosen annually by joint ballot of both Houses . . . and he shall, with the advice of a Council of State, exercise the executive powers of government.").

34. Id. at 54 ("The two Houses of Assembly shall, by joint ballot, appoint Judges of the Supreme Court of Appeals, and General Court, Judges in Chancery, Judges of Admiralty, Secretary, and the Attorney-General.").

35. N.C. Const. of 1776 , art. XIII, reprinted in 7 W. Swindler, SourCes ANd Documents of UNited States Constitutions 405 (1978) ("That the General Assembly shall, by joint ballot of both houses, appoint Judges of the Supreme Courts of Law and Equity, Judges of Admiralty, and Attorney-General.").

36. S.C. Const. of 1778, art. XXIX, reprinted in 8 W. Swindler, Sources ANd DocuMENTS OF UNITED STATES ConstrTutions 473 (1979) ("That two commissioners of the treasury, the secretary of the State, the register of mesne conveyances in each district, attorney-general, ... be chosen in like manner by the senate and house of representatives jointly, by ballot.").

37. N.C. CONST. of 1776 , art. XIX, reprinted in 7 W. SwINDLER, supra note 35 , at 405 ("The Governor ... shall have power to draw for and apply such sums of money as shall be voted by the general assembly ... . He also may . . . lay embargoes . . . have the power of granting pardons and reprieves .... and may exercise all the other executive powers of government."); S.C. CoNST. of 1778, art. XI, reprinted in 8 W. SWINDLER, supra note 36 , at 470 (providing " $[t]$ hat the executive authority be vested in the governor and commander-in-chief").

38. 1 The First Laws of the State of North Carolina § LXVIII, at $311 \mathrm{~J}$. Cushing ed. 1984).

39. The First Laws of the State of Connecticut 10-11 (J. Cushing ed. 1982).

40. A post-1854 statute appears to have reorganized the courts. Subsequent references to the judicial appointment of prosecuting attorneys place the power with "superior" courts. ConN. GEN. STat. tit. 11, $\$ 35$ (1866). Connecticut retained some form of judicial involvement in the appointment of state's attorneys until 1985. See Conn. Gen. STAT. ANn. tit. 51, § 51-278 and historical note (West 1985 \& Supp. 1988). 
fundamental law. The Constitution of 1818 not only vested the executive power in the governor, but required the governor to take care that the laws be faithfully executed-in a charge identical to the President's. ${ }^{41}$ Moreover, there is no provision in the article on the judiciary independently authorizing the judicial appointment of prosecutors. Thus, Connecticut's practice of judicial appointments for criminal prosecutors persisted in the face of a separation of powers system worded identically in relevant respects to the federal Constitution.

Finally, under the Delaware Constitution of 1776, the Attorney General was appointed by the Governor together with a privy council consisting of four members of the legislature. ${ }^{42}$ Moreover, courts had statutory authority to appoint prosecutors in any case in which the Attorney General or a designated deputy failed to appear. ${ }^{43}$

If criminal prosecution were conventionally thought to fall inherently under executive authority, the links just recounted between prosecuting authorities and state courts or legislatures would be anomalous. The one other piece of contemporary evidence as to common understanding, however, bolsters the conclusion that prosecution need not be an executive function, and that the state practices just recounted were consistent with conventional understanding. In England, criminal prosecution was still largely a private function. ${ }^{44}$ There was a degree, now enlarged, to which the English Attorney-General could supervise criminal prosecutions. In

41. Conn. Const. of 1818 , art. IV, $\S \S 1,9$, reprinted in 2 W. SWINdLer, Sources and Documents of United States Constrtutions 147-48 (1973).

42. DEL. ConsT. of 1776 , art. 8, provides that "[a] privy council, consisting of four members, shall be chosen by ballot, two by the legislative council and two by the house of assembly...." Article 12 charges the governor and the privy council with appointing various officers, including the attorney-general. $2 \mathrm{~W}$. SwINDLER, supra note 41 , at 200 01 .

43. 1 Laws of the State of Delaware, ch. XIII, \& 2 (1797). Of the five states discussed above, only Connecticut, as of 1818 , had a faithful execution clause worded identically to the U.S. Constitution. The Constitution of South Carolina and the Declaration of Rights of Delaware and of North Carolina, however, each prohibited the executive suspension of statutes. S.C. ConsT. of 1778, art. XXIV, reprinted in 8 W. SwINDLER, supra note 36, at 474; Del. Const., Declaration of Rights and Fundamental Rules, cl. 7 , reprinted in 2 W. SWINDLER, supra note 41, at 198; N.C. CoNST. of 1776, A Declaration of Rights, art. V, reprinted in $7 \mathrm{~W}$. SWINDLER, supra note 35, at 402 . If I am correct that the original import of the federal faithful execution clause is identical to the English prohibition on the royal suspension of statutes, then there is no textual difference between the state and federal constitutions relevant to the controversy whether criminal prosecution was inherently executive. See Brlz of Righrs $\$ 1,1$ W. \& M., 2 d sess., ch. 2 (1689), reprinted in 4 ThE Founders' Constitution 123 (P. Kurland \& $\mathrm{R}$. Lerner ed. 1987).

44. J. Jacoby, The American Prosecutor: A Search for Identity 7-11 (1980); J. Beattie, Crime and the Courts in ENGland 1660-1800, at 35-36 (1986). Indeed, private parties in England still retain authority in principle for the commencement of prosecutions. E. Wade \& A. Bradley, Constitutional and administrative Law 356 (1985). 
making prosecutorial decisions, however, the Attorney-General was regarded as an independent officer, personally accountable to Parliament, whose judgments were not controlled by the Crown or by the Prime Minister. ${ }^{45}$

In sum, an originalist from the Planet Meese, like the textualist from the Planet Mars, should find Morrison an easy case. Historical argument indicates that the degree of autonomy that an independent counsel enjoys cannot undermine constitutionally vested executive power over criminal prosecution for a simple reason: the Constitution does not require criminal prosecution to be at all the exclusive domain of the executive branch. The Reagan administration's contrary position was in error under its own preferred method of interpretation.

\section{Argument from Precedent}

Formalists from earth might also argue that, notwithstanding the clear implications of both constitutional text and late eighteenth century history, criminal prosecution has become an inherently executive power because federal courts and the federal executive have for so long so regarded it. Dicta in several federal judicial opinions do refer to prosecutorial discretion as being "executive." 46

To this argument, there are two important responses. The first comes from Mr. Meese, who caused a political stir by arguing that the Constitution is something different from what interpreters, including the courts, say about it. Except in the decided case itself, the country need owe no allegiance to constitutional law, the Attorney General said, when the law is wrong. ${ }^{47}$ Thus, even if the courts (or, self-servingly, the executive) did repeatedly characterize criminal prosecution as an executive function, we should be prepared simply to dismiss that conclusion as wrong when the text and original history both show the interpretation to be so unpersuasive. Such is the case here.

The second, of course, is that dicta are not law. While it is true that a number of judicial opinions characterize criminal prosecution as an executive function, this characterization is not actually necessary to explain what such rhetoric is usually invoked to justify, namely, the deferential stance of the federal judiciary towards prosecutorial decisionmaking by someone other than a court. In

45. E. Wade \& A. Bradley, supra note 44 , at 358 .

46. E.g., United States v. Nixon, 418 U.S. 683, 697-713 (1974) (commenting that "the Executive Branch has exclusive authority and absolute discretion to decide whether to prosecute a case"); United States v. Cox, 342 F.2d 167, 171 (5th Cir.) (refusing to compel an United States attorney to sign indictments returned by the grand jury, reasoning that "it is as an officer of the executive department that [the United States attorney] exercises a discretion as to whether or not there shall be a prosecution in a particular case"), cert. denied, 381 U.S. 935 (1965). See The Confiscation Cases, 87 U.S. (20 Wall.) 92 (1873) (refusing to compel prosecutions involving confiscated property on behalf of informants who stood to acquire such property as reward upon successful prosecution).

47. Meese, The Law of the Constitution, 61 Tul. L. REv. 979, 981-83 (1987). 
light of the textualist and originalist support for independent counsels, formalists should agree that contrary dicta should have no force in attacking independent counsels if there is a fully persuasive alternative theory explaining the results of cases in which such characterizations appear.

The courts' deference to prosecutorial discretion is entirely accounted for under a theory of government called "separation of functions." 48 By this, I mean the prescription for distributing government power that focuses on the unfairness of melding the powers to make rules, to enforce rules, to interpret rules, and to impose sanctions for rule violations all in the same actor. For example, modern administrative agencies typically exercise each of these functions somewhere within each agency. Therefore, structural protections such as the ban on ex parte contacts between prosecuting attorneys and attorneys advising the agency on its ultimate decisionmaking are used to assure fairness. ${ }^{49}$ Their functions are separated. What is critical from the separation of functions point of view-a point of view most clearly rooted in due process ${ }^{50}$-is not that the executive branch have plenary discretion regarding prosecution, but that article III judges do not become unduly involved in the decisions whether and with what to charge individuals in the first place. Such involvement would be wrong because judges may be finders of fact, adjudicators of law, and sentencers in criminal cases.

Separation of functions theory provides a coherent explanation for the courts' reluctance to engage in any but the most marginal oversight of prosecutorial decisionmaking. The public might perceive that a judicial failure to defer to prosecutorial decisionmaking would implicate our adjudicators too strongly in initial charging decisions. This would breach the separation of functions and threaten the commitment to due process that the Constitution manifests. Because references to prosecution as an "executive" function can thus be explained as meaning only that prosecutorial discretion should not be usurped by courts, ${ }^{51}$ they do not provide any weighty legal support for the argument that criminal prosecution must be conducted by a prosecutor subject to plenary presidential policy control. The Ethics in Government Act would be objectionable on

48. The relationship between separation of functions ideas and separation of powers theory is explored in Verkuil, Separation of Powers, The Rule of Law and the Idea of Independence, 30 WM. \& MaRY L. Rev. 301 (1989).

49. See Adminstrative Procedure Act, $\S 5(d), 5$ U.S.C. $§ 554(d)$ (1982).

50. Verkuil, supra note 48 , at 341 .

51. "[A]s an incident of the constitutional separation of powers, ... the courts are not to interfere with the free exercise of the discretionary powers of the attorneys of the United States in their control over criminal prosecutions." United States v. Cox, 342 F.2d 167, 171 (5th Cir.), cert. denied, 381 U.S. 935 (1965). 
separation of functions grounds if it vested courts with sufficient supervisory authority over prosecution to implicate courts in the actual charging decision. Because that is not the case, the statute is unobjectionable on this ground.

*** $*$

In sum, Morrison $v$. Olson is an easy case from a formalist point of view. The text strongly vindicates Congress's authority to design the office of independent counsel as it has. Originalist history shows that the founding generation did not conceive of criminal prosecution as an inherently or exclusively executive function. Prior references in judicial decisions to criminal prosecution as an executive function are dicta, explainable as a shorthand reference to the inappropriateness of subjecting prosecutorial discretion to excessive judicial supervision.

\section{Independent Agencies: Formalism and Modernism}

\section{A. What is at Issue?}

Independent counsels are relatively rare creatures compared to a much better known variety of independent adminstrator, namely, the heads of what are often called "independent agencies." Unfortunately, to speak-as commentators often do-of the constitutionality of some undifferentiated phenomenon called an "independent agency" is to put the problem misleadingly. Federal agencies do not come in two discrete models, one "executive" and one "independent," that are recognizable by clearly distinguishable characteristics. ${ }^{52}$ Questions concerning the constitutionality of various aspects of agency design and operation must be asked and resolved with much greater specificity.

The general reason why some agencies are informally denominated "independent agencies" is that certain of their features are designed to mitigate the degree to which partisan politics can dominate their decisionmaking. Not all of these structural features are controversial. Well-accepted accoutrements of independence include the adoption of collegial decisionmaking, staggered terms for the agency's prime decisionmakers, terms of office that are longer than the four-year presidential term, and quotas on the number of agency members who may belong to either of the major parties. There is no current challenge to the constitutionality of any of these politics-mitigating features.

The one aspect of some agencies' independence that has attracted current challengers is the supposed immunity from removal of certain agency heads who refuse to follow the policy directives of the President. Although these "independent" administrators are apparently removable "for cause," it is conventionally understood that it would not be cause for removal that such an administrator declined

52. Strauss, The Place of Agencies in Government: Separation of Powers and the Fourth Branch, 84 Colum. L. Rev. 573, 583-85 (1984). 
to follow the President's policy preferences in favor of policy initiatives that the administrator prefers and which are also within the administrator's lawful discretion. This insulation from direct presidential policy supervision is the aspect of agency design that is most provocatively independent, and it may be most helpful to refer to such insulation as "policy independence."

Were it not for statutory limits on the removability of independent commissioners, challengers to agency policy independence assume that the President could lawfully supervise the way in which all administrators exercise their policymaking authority. As to "purely" executive or "non-independent" administrators, it is presumed that the President is constrained only by the requirement that he not direct any act beyond the bounds of an administrator's legal authority. ${ }^{53}$ In contrast, the President's direct supervisory authority over independent agency commissioners is limited identically to his authority over independent counsel-he may police such officials for legal compliance, but no more.

It is not obvious what practical significance currently attaches to agency independence. Despite the theoretical interest inherent in the constitutional issues, no one has comprehensively assessed the impact on agency policymaking of whatever insulation from direct presidential supervision such agencies enjoy. Independent agencies, even if not required to do so, may nonetheless choose to align their policies with those of the President. ${ }^{54}$ It is hard to imagine that the Federal Trade Commission under James C. Miller III, for example, could have cooperated any more fully than it did with the Reagan administration's philosophy of economic regulation. Conversely, "executive" agencies may not always be as cozy towards the White House as might be imagined. The Environmental Protection Agency under William Ruckelshaus tried to maintain at least something of an arm's-length relationship to the President. The "independent" Civil Aeronautics Board was abolished in the late 1970 s, and its functions folded into the "purely executive" Department of Transportation. ${ }^{55}$ It is an open question whether this shift had any policy impact at all.

Furthermore, conventional understanding of the legal limits on

53. Compare Sierra Club v. Costle, 657 F.2d 298 (D.C. Cir. 1981) (upholding EPA regulations against challenge that non-record presidential communications affected exercise of agency policymaking discretion), with Kendall v. United States ex rel. Stokes, 37 U.S. (12 Pet.) 522 (1838) (holding that President could not direct Postmaster to act contrary to ministerial duty imposed by statute).

54. Several attempts at assessing the actual policy independence of independent agencies, most suggesting that their degree of independence is less than commonly supposed, appear in Symposium: The Independence of Independent Agencies, 1988 DukE L.J. 215, 215-99. 1703.

55. See Civil Aeronautics Board Sunset Act of 1984, Pub. L. No. 98-443, 98 Stat. 
the President's ability to direct independent administrators may amount to no more than folklore. No President has ever attempted to discharge an independent administrator for disobeying a direct presidential order to implement a policy within the administrator's lawful discretion. There is, therefore, no judicial test as to whether such disobedience would constitute cause sufficient to sustain dismissal under an independent agency's organic statute. As observed by Professor Geoffrey Miller, a leading challenger of the independent agency form, a judicial interpretation of "for cause" removal that would permit such discharges would eliminate the constitutional controversy. ${ }^{56}$

Despite these reasons for questioning the current practical significance of the dispute over independent agencies, administrative lawyers and scholars have devoted substantial energy to the fray. An authoritative pronouncement that agencies are not insulated from direct presidential supervision of their policy discretion-whether as a matter of constitutional compulsion or statutory interpretationmight invite an innovative, systematic program of independent agency supervision that would have real significance. ${ }^{57}$ Also important, a constitutional decision against the independence of independent agencies would bolster a categorical approach to separation of powers disputes that could strengthen the President's hand generally in defending other supposed aspects of presidential prerogative.

All current constitutional challenges to the political insulation of independent agencies are variations of a single argument. The challengers' shared premise is that, because the President heads the executive branch, the Constitution mandates plenary control in the President over whatever policymaking discretion Congress vests in an administrative officer outside Congress. No one questions this proposition with respect to administrators who assist the President in carrying out express article II powers. That is, no one thinks Congress may set up an independent agency to negotiate treaties, direct troops in battle, or make pardon decisions. The area of controversy is thus limited to that zone of administrative discretion that Congress delegates to persons outside Congress on issues over which Congress would have plenary policy control-and the President none-but for Congress's decision to delegate. These include such areas as trade and financial regulation, product safety regulation, and the regulation of domestic health and environmental concerns. Ghallengers to the independent agencies insist that the

56. Miller, Independent Agencies, 1986 Sup. CT. Rev. 41, 86-90.

57. President Reagan's program of regulatory oversight excluded independent agencies from mandatory participation, Exec. Order No. 12,291, § 1(d), 3 C.F.R. 127 (1981), reprinted in 5 U.S.C. $\$ 601$ note at 431-34 (1982), although the Justice Department advised in 1981 that at least certain provisions of the President's order could constitutionally be applied to those agencies. United States Department of Justice Office of Legal Counsel, Memorandum for Honorable David Stockman, Director, Office of Management and Budget, Re: Proposed Executive Order on Federal Regulation (Feb. 12, 1981), reprinted in P. Shane \& $\mathrm{H}$. Bruff, The Law of Presidential Power: Cases and Materials 355, 357 (1988). 
President must be able to supervise all such delegated policymaking discretion.

\section{B. Textualism and Policy Independence}

Textually, there are three hooks for challenges to administrative policy independence. One is that the "executive power" vested by article $\mathrm{II}^{58}$ should be read to encompass the policy supervision of all administrative officers to whom Congress delegates authority. The second, which amounts to the same thing, is that the vesting of power in a unitary Presidency - that is, in a single individual-signals an intent to consolidate policy control in a way that requires plenary presidential policy supervision. The third is that plenary presidential control of policymaking is necessary in order for the President to fulfill his obligation to "take Care that the Laws be faithfully executed."59

Each of these arguments runs into the textual hurdles that my textualist from Mars encountered in assessing independent counsel. First, nothing in article II expressly grants the President any power to remove administrative officers on policy grounds. Second, article I vests authority in Congress to pass laws necessary and proper for carrying into execution even executive powers. ${ }^{60}$ Third, the natural reading of the faithful execution clause renders it a limitation on presidential power, not a grant. ${ }^{61}$ A naive reader might entertain the possibility that the words "executive power" in article II conventionally denote illimitable control over any administrative discretion that is exercised by the government of the United States. The fact is, however, that such a reading is not conventional, either now or in 1789.62 Thus, textual analysis suggests that protecting administrative officers from direct policy supervision is a choice within the permissible legislative discretion of Congress. If such is the case for criminal prosecutors, who were familiar figures in 1789 , it is a fortiori the case with modern regulatory administrators, who were not.

58. U.S. Const. art. II, $\S 1$, cl. 1 .

59. Id. § 3 .

60. Id. art. I, $\$ 8, \mathrm{cl} .18$.

61. Tiefer, The Constitutionality of Independent Officers as Checks on Abuses of Executive Power, 63 B.U.L. REv. 59, 90 (1983).

62. The scope of debate since $\mathbf{1 7 8 9}$ over the meaning of the article II vesting clause belies any argument that a single interpretation of "executive power" is so well accepted as to be regarded as conventional. "The most obvious meaning of the language of Article II, $\S 1$, is to confirm that the executive power is vested in a single person, but almost from the beginning it has been contended that the words mean much more than this simple designation of locus." Congressional Research Serv., The Constitution of the United States of America: ANalysis and Interpretation, S. Doc. No. 82, 92d Cong., $2 \mathrm{~d}$ Sess. 431 (1973). For a brief review of contending theories of executive power, see P. Shane \& H. Bruff, supra note 57, at 4-20. 
At this point, however, many constitutionalists will not be satisfied. The issue seems too weighty to ignore what may be historical or normative support for the challenge to independent agenciesarguments that may not be clearly manifested in constitutional language, but which might be persuasive once surfaced.

It is important to note, however, that once we go beyond the surface text, there are different and distinct ways of casting the argument for plenary presidential control over administrative policymaking. I shall call these "originalist" and "modernist." Logic compels the originalist to argue two propositions: first, that the founding generation addressed the issue of administrative policy control in a way that is reasonably analogous to our understanding of that issue; second, that, insofar as they understood the problem as we might, the "framers" and "ratifiers" vested administrative policy control in the President.

The modernist takes a more functional tack. The modernist concedes that the problem of administrative discretion in 1989 bears little resemblance to the problem as understood in 1789. The founding generation, however, decided quite deliberately on a unitary presidency in order to vindicate certain values-accountability, most notably-that are still worthy and of obvious relevance to the control of administrative discretion as we understand it. ${ }^{63}$ In order to protect the general values we impute to the Constitution, the modernist insists we must vest in the President plenary policy supervision over administration.

The modernist argument as I have put it still maintains a link to originalism. No one appears to argue against the constitutionality of independent agencies from a full-fledged modernist stance-for example, that, wholly without regard to values conventionally traceable to the Constitution, independent agencies are patently so bad for government that they should be struck down as unconstitutional on empirical, functional grounds. The modernist argument as I have cast it is, as Professor Miller would say, "neoclassical."64 It is value-oriented, but purports to draw only on values that interpreters can plausibly argue are signaled by the debates and decisions of the founding generation. What makes the argument modern is that it draws on those values at a level of abstraction so far removed from any context recognizable to the founding generation that it becomes misleading to regard the argument as an argument from "original intent." Although I do not believe that either the originalist or the modernist form of the argument against agency policy independence is persuasive, I do believe that the modernist argument is more internally coherent, subtler, and thus weightier.

63. C. Thach, The Creation of the Presidency 1775-1789, at 89-90 (1923); Strauss, supra note 52 , at 599-600.

64. Miller, supra note 56, at 52-58. 


\section{Originalism and Policy Independence}

The originalist argument against independent agencies cannot sustain either proposition it asserts-either that the founding generation addressed the issue of administrative policy control in a way that is reasonably analogous to our understanding of that issue, or that, insofar as they understood the problem, the "framers" and "ratifiers" vested administrative policy control in the President.

Originalists correctly insist that the organization of the presidency was one of the most important structural questions debated in connection with the framing of the Constitution. It is equally clear that the express constitutional design, relying on a "unitary president," was intended to promote accountability and "energy" in the executive. What these premises imply for administrative agencies, however, depends on the particular conception of accountability that the founding generation perceived as linked to its structural design. It is just on this point that the originalist attack on independent agencies suffers the fallacy of anachronism.

Modern originalist challengers to independent agencies assert that such agencies mitigate the President's intended accountability for the policy content of administrative decisions, that is, his political accountability. ${ }^{65}$ It is today urged that power be centralized in the President so that voters will know whom to blame if administrative policy is too "liberal," too "conservative," too "cost-insensitive," or too oblivious to nonmonetizable values. The politicized modern framework, however, is not the framework within which the founding generation conceptualized the President's accountability. To the extent that the executive was thought to enjoy discretion in carrying out congressional enactments not pertaining to military or foreign policy, the accountability that contemporaries expected pertained to what we would now categorize as managerial accountability. The executive was to keep within lawful bounds, spend public funds carefully, and deal with problems evenhandedly. The President's duty to take care that the laws be faithfully executed was an obligation, not a source of power. It incorporated into the Constitution the English prohibition on the executive suspension of statutes. ${ }^{66}$ When, for example, Publius discusses government administration, it is not in terms of its policy orientation, but rather

65. Strauss \& Sunstein, The Role of the President and $O M B$ in Informal Rulemaking, 38 ADMIN. L. REv. 181, 190 (1986).

66. "That the pretended power of dispensing with laws, or the execution of laws, by regal authority, as it hath been assumed and exercised of late, is illegal." BILL OF Rights $\S 2,1 \mathrm{~W}$. \& M., $2 \mathrm{~d}$ sess., ch. 2 (1689), reprinted in 4 The Founders' Constiturion, supra note 43 , at 123 . 
in terms of whether administration will prove "good" or "bad."67 Merit, not policy, was the criterion for judging administration.

The idea that the President was to be a source of political accountability for government policy, as we currently understand it, is implicitly refuted by the original design for presidential elections. The electoral college was conceived as a repudiation, ultimately unsuccessful, of our now partisan and plebiscitory presidential politics, in favor of a meritocratic vision of the presidency. ${ }^{68}$ Indirect election was supposed to mitigate the degree to which politics might control the choice of Presidents. Electors were even required to cast their votes in the separate states to prevent political discussion among them from influencing their choice. ${ }^{69}$

Indeed, an obvious implication of the unitary presidency is that political representativeness of the kind associated with the House of Representatives is not a goal of the executive organization. A multimembered body would clearly have created greater opportunities for popular representation than the executive branch-for example, by geographic region-and consequently greater political accountability. Implicit in the choice of a unitary presidency was the view that the President was not to be a mirror of popular sentiment, but-as far as legislation was concerned-a defender of a unitary public interest in any case should political faction overtake public good. In this respect, his function was akin to the anticipated function of the highly undemocratic Senate. ${ }^{70}$ Thus, any argument that central presidential administrative authority is necessary to preserve political accountability is based on a democratic theory different from the original constitutional vision. The repository of the Framers' commitment to democracy, such as it was, was not the executive, but Congress-primarily, the House of Representatives. ${ }^{71}$

An originalist might, of course, retreat to the argument that the Framers' commitments to centralized managerial accountability and energetic decisionmaking are enough to require centralized presidential authority over all administrative agencies. This argument, however, is weak for two reasons. First, it is by no means clear that Congress has today precluded the President from exercising a central managerial role over the agencies. Congress has provided the Office of Management and Budget-and thus the President-with a critical role in evaluating the independent agencies' budget requests $^{72}$ and paperwork requirements. ${ }^{73}$ The President is typically

67. J. Rohr, To Run a Constitution: The Legitimacy of the Administrative STATE 1-3 (1986).

68. See generall' R. Ketcham, Presidents Above Party: The First American PresiDENCY, 1789-1829 (1936).

69. U.S. Const. art. II, $\S 1$, cl. 3. On the meritocratic vision of the presidency, see also The Federalist No. 68 (A. Hamilton).

70. J. RoHr, supra note 67, at 29-32.

71. George Mason called the House "the grand depository of the democratic principle of the Government." G. WoOd, The Creation of the American Republic 17761787 , at 553 (1969).

72. See 31 U.S.C. $\S 501$ (1982 \& Supp. IV 1986) (establishing the Office of Management and Budget). 
permitted to choose the chair of each multi-member agency. ${ }^{74}$ "Inefficiency" and "neglect of duty" are often mentioned in the statutes authorizing independent agencies as causes sufficient to sustain the presidential removal of even an independent administrator. ${ }^{75}$ All of this comports with a vision of constitutionally compelled centralized management.

A careful originalist, however, should regard even these congressional decisions to be constitutionally discretionary. Whatever commitment the founding generation had to centralized management did not translate-even in the late eighteenth century-into a model of executive control over all administration at the state or federal level. We have already seen that this is true with respect to criminal prosecutors, who are, after all, administrative policymakers. Evidence regarding civil administration also supports the point.

In 1789, the first Congress created four civil administrative establishments - the departments of War, of Foreign Affairs, of the Treasury, and of the Post Office. ${ }^{76}$ Congress's treatment of the four agencies reflected lengthy deliberation and differing understandings as to the relation of executive power to each agency.

Two of the departments-War and Foreign Affairs-were understood to be assisting in the implementation of presidential powers vested specifically by the Constitution and were denominated "executive departments."77 Their organic statutes sketched their departmental organization and their duties only in broad terms. Congress anticipated a broad supervisory relationship of the President to the department. ${ }^{78}$

The new Post Office establishment, however, was not called a department. ${ }^{79}$ The Postmaster General had a reporting relationship to the Secretary of the Treasury, and it is clear from the debates

73. See Paperwork Reduction Act of 1980, Pub. L. No. 96-511, 94 Stat. 2812 (codified as amended at 44 U.S.C. $\$ \$ 3501-3520$ (1982 \& Supp. IV 1986)).

74. See, e.g., 15 U.S.C. $\$ 2053$ (a) (1982) (Consumer Product Safety Commission); 42 U.S.C. $\$ 5841$ (a) (1982) (Nuclear Regulatory Commission).

75. See, e.g., 15 U.S.C. $\$ 2053$ (a) (1982) (Consumer Product Safety Commission); 42 U.S.C. $\$ 5841$ (e) (1982) (Nuclear Regulatory Commission).

76. J. Sanders, Evolution of Executive Dep'ts of the Continental Congress 1774-1789, at 187-92 (1935); Casper, An Essay in Separation of Powers: Some Early Versions and Practices, 30 WM. \& MARY L. Rev. 211, 233-42 (1989).

77. Casper, supra note 76, at 239.

78. Id.; see Act of July 27, 1789, ch. 4,1 Stat. $28-29$ (establishing the Department of Foreign Affairs); Act of Aug. 7, 1789, ch. 7,'1 Stat. 49-50 (establishing the Department of War). Even so, it was by no means clear to the first Congress that the President was constitutionally vested with plenary removal power over the heads of these departments. On the ambiguities surrounding early removal controversies and the so-called "Decision of 1789," see L. Fisher, Constitutional. Conflicts Between Congress and the PresiDENT 60-66 (1985).

79. J. SANDERS, supra note 76, at 192. 
surrounding the Treasury Department that the character of Treasury was not perceived to be executive in a manner akin to the departments of War and Foreign Affairs. ${ }^{80}$ First, unlike the other departments, Treasury was not denominated "executive" by statute. Congress went to great length to specify the Department's structure, creating a number of fiscal officers with reporting responsibility to the Secretary. ${ }^{81}$ Most tellingly, the first Congress perceived the Secretary's obligations as running to Congress as well as to the President. The most important debate in this regard centered around a proposed duty of the Secretary "to digest and prepare plans for the improvement and management of the revenue, and for the support of public credit." 82 This wording is nearly identical to the charge to the financial officers authorized under the Articles of Confederation. ${ }^{83}$ Some in Congress were alarmed that this parliamentary duty would so involve the Secretary in legislation as to undermine the authority of the House; others saw the charge as undermining the President's power to propose legislation. Nonetheless, Congress conferred this duty upon the Secretary, essentially borrowing a description of the Secretary from this country's former, short-lived parliamentary system.

The implications of this analysis were borne out in practice. For several years, the Secretary of the Treasury functioned as the Committee on Ways and Means of the House of Representatives. ${ }^{84}$ As late as 1823, the Attorney General advised the President that, far from the President being constitutionally obligated to correct an allegedly improper settlement by the Treasury Department of an individual's claim for reimbursement, it would be legally impermissible for the the President to substitute his judgment for that of the accounting officer. ${ }^{85}$

The vision of an air-tight executive establishment under plenary presidential control that is conjured by originalist challengers to independent agencies thus cannot be matched by the early history of administrative practice. One noted commentator has gone so far as to say that the Constitution, as adopted and implemented in 1789 , actually marked the repudiation of the separation of powers principle. ${ }^{86}$ Dean Gerhard Casper's observations, however, may come

80. Casper, supra note 76 , at $240-42$.

81. Id at 240.

82. Id. (quoting 1 Stat. at 65-66 (1789)); see J. RoHR, supra note 67, at 18-27.

83. J. RoHR, supra note 67 , at $22-23$.

84. Casper, supra note 76 , at 241 . The flexibility of the founding generation in administrative design is also illustrated by Congress's 1791 decision to charter the National Bank of the United States. Despite the critical importance Hamilton attached to the bank as the federal government's fiscal agent, he successfully urged Congress-insofar as possible-to place the bank under private direction, which would bolster public confidence in the bank. Act of Feb. 25, 1791, ch. X, 1 Stat. 191, 193 (obsolete).

85. The President and Accounting Officers, 1 Op. Att'y Gen. 624, 625 (1823).

86. F. McDonald, Novus Ordo Seclorum: The Intellectual Origins of the CoNSTITUTION 258 (1985). 
closer to the mark. Casper regards late eighteenth century government decisionmakers as not having had before them any single, coherent vision of a "separation of powers" principle either to adopt or to reject. ${ }^{87}$ Instead, they were intent on structuring an administrative apparatus that would be but one version of a government of largely separated powers. The aims of this structure were functional, to balance the need for effective, coordinated administration with the need to protect against tyranny. The failure of a modern Congress to respect any single, coherent vision of a separation of powers principle thus does not run afoul of any original understanding.

\section{Modernism and Policy Independence}

By now, any thoroughgoing originalist should be persuaded that the decision whether to insulate agency administrators from direct presidential policy supervision is wholly within congressional discretion. Neither the text nor the history relevant to original understanding of the separation of powers commands plenary control in the President.

Yet, originalism in this context seems almost a sleight of hand. To put it bluntly: why should we be bound, in our understanding of the President's proper role vis-a-vis a vast modern administrative bureaucracy, by the conventional conceptualization of administration in an entirely different world? An additional and perhaps more provocative level of constitutional argument is possible.

As I noted briefly above, one might start this argument, like the originalist argument, by observing that the Constitution clearly embodies a commitment to a unitary executive and that the fundamental purpose underlying the constitutional organization was executive accountability. It may be conceded that the terms in which the Framers discussed accountability were not the policy-laden, frankly partisan terms by which we understand the concept. They assessed administration in terms of virtues "above" politics-was administration honest or corrupt, efficient or inefficient, dedicated to the public good or overtaken by faction? But the differences in the terms by which they and we understand our very different worlds do not belie the shared concern. It is arguably as legitimate for us as it was for them to build a contemporaneous conception of accountability into our reading of the constitutional text. This is so, the modernist urges, even without a formal alteration of that text.

The difference between this argument and a genuinely originalist argument can be illustrated by comparing two Supreme Court opinions regarding another structural dimension of the Constitution,

87. Casper, supra note 76, at 212, 224. 
namely, federalism. In 1976, then-Associate Justice Rehnquist wrote for the Court an opinion invalidating part of the Fair Labor Standards Act ${ }^{88}$ because it violated a judicially enforceable protection for states' rights that the majority purported to find in an originalist view of the Tenth Amendment. ${ }^{89}$ Justice Brennan's dissent persuasively argued that the majority had essentially invented its original understanding, ${ }^{90}$ and the weakness of the majority's rhetoric may have helped insure a short life to its holding. ${ }^{91}$

In contrast, Justice O'Connor in 1982 wrote a modernist dissent from a decision upholding another attempt at federal regulation of the states. ${ }^{92}$ She provided a more compelling (though ultimately unsuccessful) rationale for Justice Rehnquist's approach. Justice O'Connor recapitulated the virtues of federalism that the founding generation hoped to secure and argued for the increased importance of those virtues under modern government. She then argued, in essence, that those virtues could not be preserved in a modern United States without creating a judicially enforceable federalism principle and locating it in the Tenth Amendment. ${ }^{93}$ In avoiding any reliance on an historical claim that her reading of the Tenth Amendment was the original reading, she freed herself to make the more subtle and less vulnerable argument that her reading was necessary to vindicate original constitutional concerns about democracy, pluralism, and the decentralization of power under vastly changed economic and social circumstances.

The modernist argument against independent agencies runs as follows. The Constitution created a unitary presidency in order to concentrate accountability in the President. Although the original constitutional vision of administration was essentially meritocratic, we have come to perceive that the administrative implementation of public policy is infused with political value judgments. The founding generation believed that House of Representatives elections would preserve political accountability, yet that is clearly not the case. An electorate unable to influence the policies that guide the exercise of administrative discretion in the executive branch is significantly disenfranchised. The way to preserve our commitments to democracy and to accountability is by reading into Article II a plenary presidential power to guide executive branch policymaking. ${ }^{94}$

88. Fair Labor Standards Amendments of 1974, Pub. L. No. 93-259, § 6(a), 88 Stat. 55 (extending the Act's minimum wage and maximum hour requirements to the states).

89. National League of Cities v. Usery, 426 U.S. 833, 840-52 (1976).

90. Id. at 860-63 (Brennan, J., dissenting); see also Powell, The Compleat Jeffersonian: Justice Rehnquist and Federalism, 91 YALE L.J. 1317 (1982) (arguing that Justice Rehnquist's theory of federalism as it emerged in National League of Cities was not based on constitutional first principles intended by the Framers).

91. See Garcia v. San Antonio Metro. Transit Auth., 469 U.S. 528 (1985) (overruling National League of Cities).

92. FERC v. Mississippi, 456 U.S. 742, 775 (1982) (O'Connor, J., dissenting).

93. Id. at 787-96.

94. Cf. McConnell, W'hy' Hold Elections? L'sing Consent Decrees to Insulate Policies from Political Change, 1987 U. CHi. Legal F. 295 (arguing that consent decrees that bind the administrative discretion of federal agencies undermine democratic accountability embodied in presidential authority over administrative policymaking). 
This argument is more compelling, it might be urged, because of thoroughly changed political, social, and economic circumstances. First, although the democratic character of the original Constitution was significantly attenuated, formal changes in the Constitution since 1789 have enlarged its commitment to popular democracy and electoral control. ${ }^{95}$ Because Congress now delegates such extensive policymaking authority to administrative agencies, placing ultimate policy authority in the President is the most effective mechanism for giving voters influence over the policy agenda of the agencies. ${ }^{96}$

Second, the limited scope of federal activity in the late eighteenth century, especially with regard to domestic regulation, made it plausible to think Congress would keep to itself all significant discretion over federal policymaking. The scope of modern federal government activity is, by contrast, enormous, prompted by the creation of national markets and national networks of communication and transport, as well as by the reallocation of civil rights authority following the Civil War. The fact that Congress has responded by delegating important policymaking discretion with respect to virtually every aspect of our collective economic and social life creates a critical problem of coordination. The President is the only official with the current capacity to impose some coordinating discipline on a host of administrators, each of whom may otherwise fail to take account of the competing agendas of different agencies. ${ }^{97}$

Finally, a core aspiration articulated by Madison for the new government structure was its utility in overcoming what Madison called the vices of "faction." To whatever extent eighteenth century social and political conditions might have rendered that hope realistic, modernists insist that our current Congress and the agencies are easy prey to narrow interests, the current analogues to factions. ${ }^{98}$ The President, because he has the broadest possible constituency, is least likely to fall prey to special interests. The unitary presidency thus has a potentially critical role to play in countermanding the modern influence of faction in administrative policymaking. ${ }^{99}$

95. "Passage of the Fifteenth, Seventeenth, and Nineteenth Amendments shows that [the eighteenth century] conception of political equality belongs to a bygone day. ..." Gray v. Sanders, 372 U.S. 368, 377 n.8 (1963) (holding that states may not structure gubernatorial elections to resemble the electoral college system where the state structure violates the one person, one vote requirement).

96. Mashaw, Pro-Delegation: Why Administrators Should Make Administrative Decisions, $1 \mathrm{~J}$. LAW, ECON. \& ORG. 81 (1985).

97. See generally Strauss \& Sunstein, supra note 65.

98. See, e.g., B. ACkerman \& W. Hassler, Clean Coal/Dirty Air 121-28 (1981) (discussing the role of organized interests in writing the Clean Air Act).

99. Sunstein, Constitutionalism After the New Deal, 101 Harv. L. REv. 421, 452-63 (1987). 
These are important arguments, made at greater length and perhaps with additional subtlety by others. They do not rest on artificial attempts to capture what the founding generation thought, but instead urge what we should now think in applying the general concepts of accountability and coordination to our modern circumstance. If one regards constitutional argument in the modern neoclassical mode as legitimate, these arguments provide weightier ammunition than does originalism for the constitutional position advanced by the Reagan administration on the independent agency controversy.

These arguments are weightier than the originalist challenge, although, to be sure, each modernist argument is questionable on its own terms. It is by no means clear in practice that increased presidential control over agency policymaking would be truer to the electoral will than the current system. Despite President Reagan's overwhelming electoral mandates, popular opinion never swung behind key elements of his deregulatory agenda. It is plausible that public enthusiasm for the President was strengthened by the perception that he could not disturb major elements of domestic social policy that were embedded in legislation and in our bureaucratic culture before his presidency.

Likewise, coordination in the administration of statutes is a virtue only to the extent Congress wants coordination. A key anxiety underlying President Reagan's increased oversight of regulatory policymaking by non-independent agencies ${ }^{100}$ concerned the degree to which the Office of Management and Budget might try to enforce policy uniformity contrary to legislative intent. ${ }^{101}$ Although it is plausible that presidential oversight can help to "minimize duplication and conflict of regulations," 102 this is a proposition to be tested empirically. Moreover, improvements in this regard need to be balanced against the degree to which such coordination threatens to undermine the effectiveness of individual statutory programs.

The President's precise role in resisting "faction" is likewise far from self-evident. Modern laments against "special interests" do not equate precisely with Madison's notion of faction. Madison defined faction as

a number of citizens, whether amounting to a majority or minority of the whole, who are united and actuated by some common impulse of passion, or of interest, adverse to the rights of other citizens, or to the permanent and aggregate interests of the community. ${ }^{103}$

100. Exec. Order No. 12,291, 3 C.F.R. 127 (1981), reprinted in 5 U.S.C. $\$ 601$ note at 431-34 (1982); Exec. Order No. 12,498, 3 C.F.R. 323 (1986), reprinted in 5 U.S.C.A. $\S 601$ app. at 296-97 (West Supp. 1988).

101. Sunstein, Cost-Benefit Analysis and the Separation of Powers, 23 ARIz. L. REv. 1267, 1272-82 (1981).

102. Exec. Order No. 12,291, Preamble, 3 C.F.R. 127 (1981), reprinted in 5 U.S.C. $\S 601$ note at $431-32$ (1982).

103. The Federalist No. 10, at 57 (J. Madison) (J. Cooke ed. 1961). 
Thus, organizations dedicated, for example, to environmental protection or civil rights enforcement-organizations that President Reagan was wont to decry as special interests-do not represent "factions" in the Madisonian sense because their ideological appeal is to the long-term common interest, not to momentary passion or self-interest. ${ }^{104}$ The modern "special interests" most obviously resembling Madisonian factions are the lobbyists and political action committees organized for the protection of economic interests. That these organizations might be more effectively deployed against independent agencies than non-independent agencies is an intriguing empirical proposition that must be tested, not merely assumed.

For constitutional purposes, however, the modernist arguments, whatever their empirical basis, are unpersuasive because they are incomplete. Accountability, coordination, and the obstruction of factionalism are not the only relevant general concepts that are both traceable to the Constitution and translatable for modern application. Two other constitutional principles are critically importantthe diffusion of power and the primacy of Congress in domestic policymaking.

The diffusion of what we would now call regulatory power was of critical significance to late eighteenth century political thought.105 The Constitution thus recognizes the continuing integrity of state governments, divides the branches of the federal government, and bifurcates the federal legislative branch. Swings in popular majorities can swing the House of Representatives every two years, but not the Senate. Most regulatory power was thought to reside in the states, wherein the source of regulation most clearly analogous to our independent agencies was the common law court. The result is a deliberate impediment to coordination.

The contribution to liberty of the diffusion of power has long been treated as all but self-evident in American political thought. Our political evolution, however, has demonstrated an additional value-the profound contribution of this diffusion of power to political stability. The increased democratization of American politics has exposed deep divisions within the electorate on basic political and social questions. We have witnessed profound changes in majority sentiment on a variety of issues within even the past three decades. Because policymaking power is diffused, however, throughout different branches and among different levels of government, two things are true. Even a strong majority is likely to produce no more than incremental policy changes in short periods of time, and minority opinion, defeated in one forum, is likely to have

104. Tesh, In Support of "Single-Issue" Politics, 99 PoL. Scr. Q. 27 (1984).

105. A classic statement is, of course, The FEDERALIST No. 10 (J. Madison). 
other political forums in which to compete more effectively. This means that a political minority, when it loses an election, does not lose everything. Much less does it lose everything if its opinion was ever majority opinion and, hence, embodied in laws that would have to be repealed if another philosophy is to be implemented as law. Given how hotly the public currently contests such issues as abortion, civil rights, environmental protection, public aid to religion, and trade policy, it may be quite dangerous to raise the policy stakes in presidential elections. Empowering temporary majorities to swing quickly the whole of our policy agenda may greatly provoke electoral discontent and social strife.

This is all the more true because so much regulatory power has passed to the federal government. The development of national markets, and of national networks of communication and transport, has rendered it highly unlikely that judicially enforceable federalism. principles can ever be sensibly devised to reduce the federal regulatory role. ${ }^{106}$ In a sense, congressional decisions to vest policy independence in administrative agencies may help to compensate for the diminished vitality of federalism. The relative lack of coordination among independent agencies may better accord with the pluralism and division that often characterizes the American electorate. From the standpoint of stability, the record of the more fully coordinated western parliamentary democracies of Europe does not seem enviable.

The salience of the diffusion of power to our decision as to whether Congress may authorize agency policy independence is even greater when considered in tandem with a second constitutional commitment-a commitment to the primacy of Congress in domestic federal policymaking. Whatever the advantages of that primacy in 1789, it might be thought to have at least two advantages two centuries later. First, the primacy of Congress, with its divided structure and staggered Senate selections, helps reinforce the bias towards incrementalism that we value as a source of stability. Second, although the diffusion of power within Congress through the proliferation of subcommittees undoubtedly diminishes the coordinating capacity of Congress, it greatly increases the likelihood that some politician will have real incentive to pay close attention to agency policy even at a micro-level. The prestige of a subcommittee chair-there were 228 subcommittees in 1987-88107_is likely to be augmented by that person's success in drawing attention to issues raised by the activity of any agency within his or her subcommittee's jurisdiction.

The arguments from congressional primacy and the virtues of the diffusion of power are, of course, debatable. The actual value to the

106. The inability of Tenth Amendment doctrine to account for innovation was an explicit ground for the decision overruling National League of Cities v. Usery, 426 U.S. 833 (1976). See Garcia v. San Antonio Metro. Transit Auth., 469 U.S. 528, 543-47 (1985).

107. See 1987-88 Official Congressional Directory, S. Prt. No. 31, 100th Cong., lst Sess. VI-XIII (1987). 
American polity of what independent agencies contribute by way of congressional primacy and the diffusion of power is as controversial as the value of what centralized executive power would contribute by way of coordination, political accountability, and the deterrence of faction. My conclusion, therefore, is that the arguments favoring agency policy independence are too weak to command that the President be denied policy supervision over agencies that are not exercising powers in areas of authority vested in the President by Article II.

I do believe, however, that the arguments are strong enoughcertainly as weighty for constitutional purposes as the arguments against the policy independence of agencies-that the issue as to whether policy independence is an appropriate feature of an agency is an issue within Congress's discretion to decide. There is no single argument on either side of the issue that trumps the others because it is either plainly more rooted in Constitutional values or plainly more persuasive empirically. All the arguments discussed are policy positions to be weighed in deciding as a matter of legislative judgment how it is necessary or appropriate for any individual agency to be structured. Congress is free to weigh such constitutionally rooted arguments-as well as a host of other arguments for and against independence that may not be linked rhetorically with constitutional values-because all would be within Congress's rational consideration in deciding on agency structure. ${ }^{108}$

This is plainly not a defense of particular decisions Congress has made. Critics are right that no apparent principle explains why some agencies are currently "independent" and others "purely" executive. ${ }^{109}$ That Congress may make decisions that are difficult to rationalize or even wrong does not diminish the scope of its powers to make decisions. If the policy arguments against independence are strong enough, Congress should pay heed. My point is, however, that even the modernist Constitution favors Congress's authority to make the choice. It corroborates the likeliest inferences from a textual and historical analysis.

\section{Morrison v. Olson Reprise: Would Modernism Alter the Outcome?}

On the debate regarding the policy independence of civil regulators, I have argued that modernism provides weightier arguments

108. Economic efficiency, for example, may provide arguments against policy independence that are not constitutionally rooted. The policy arguments against independence are well reviewed in Miller, supra note 56, at 75-83. For a defense, see 5 SENATE Comm. on Governmental Affairs, Study on Federal Regulation, 95th Cong., 1st Sess. 6-8, 67-81 (Comm. Print 1977).

109. Miller, supra note 56, at 72-75. 
against independence than does originalism. My conclusion, however, was that even modernist argument favors congressional discretion regarding the decision over agency independence. Because formalist argument seems so untenable a foundation for a constitutional challenge to independent counsels, it seems fair to ask whether modernism would have better served the Reagan administration.

My own assessment is that the modernist elements in Justice Scalia's dissent in Morrison v. Olson 110 are, in fact, the most subtle and compelling. Justice Scalia argues, first, that the independent counsel offends the constitutional commitment to due process because the judicial appointment of a prosecutor to investigate a single potential defendant undermines the values of prosecutorial detachment, impartiality, and accountability. ${ }^{11}$ There is no effective political check either on such a prosecutor or on those who appoint her. ${ }^{112}$ Neither is the prosecutor's zeal for investigation and prosecution tempered by the sense of proportion provoked by competing claims for the prosecutor's time and energy-the situation faced, that is, by any United States Attorney or Justice Department prosecutor. ${ }^{113}$

The second claim is that the independent counsel law destabilizes the co-equality of the branches. ${ }^{114}$ The Constitution hands Congress specific tools to check an unlawful executive-most notably, impeachment. The obligation to appoint an independent counsel, however, arises when any person, including a member of Congress, brings the requisite information to the Attorney General. ${ }^{115}$ This gives Congress a check on the executive not contemplated by the Constitution, the very threat of which may reduce the zeal of the President's subordinates in the discharge of their duties. Furthermore, when any member of Congress successfully seeks an independent counsel to investigate a prominent executive official, the result is arguably to erode public support for the President, whether or not the charges involved prove meritorious. ${ }^{116}$

There is reason to debate whether independent counsel in practice truly augur the consequences that Justice Scalia predicts. Professor Bruff has pointed out that independent counsels have yet to bring any unsuccessful prosecutions, and potential professional embarrassment acts as a strong deterrent to overzealousness. ${ }^{117}$ It is plausible, of course, that multiple criminal investigations eroded President Reagan's support. It is less clear whether any erosion is

110. 108 S. Ct. 2597 (1988).

111. Id. at $2637-40$ (Scalia, J., dissenting).

112. Id. at $2638-39$.

113. Id. at 2640 .

114. Id. at 2630 .

115. See 28 U.S.C. $\S \S 591,592$ (g) (1982 \& Supp. IV 1986).

116. Morrison, 108 S. Ct. at 2630-31 (Scalia, J., dissenting).

117. Bruff, Independent Counsel and the Constitution, 24 Wrllamette L. Rev. 539, 557 (1988). 
traceable to the investigation rather than to the conduct of particular defendants.118 Moreover, President Reagan amply demonstrated a President's capacity to mobilize other strengths to combat any erosion of support.

There are, I would argue, two even more compelling reasons why Justice Scalia's modernism fails. The first is that it ignores competing constitutional values, just as did the modernist argument against agency policy independence. One message of the impeachment power is that Congress is accountable for checking executive abuse. It is fair to say that impeachment has not proven up to that task. Thus, Congress's innovation in creating the independent counsel may go no further in checking the President than would impeachment, were it a more practicable option. Additionally, the Constitution commands the President to take care that the laws be faithfully executed. A distortion of executive branch judgment resulting in the failure to prosecute corrupt officials would be tantamount to the suspension of a criminal statute-the precise consequence that the faithful execution clause was intended to avoid.

The second reason, however, why Justice Scalia's modernism fails is that the formalist arguments supporting Congress are simply too strong. Unless straightforward textualism produces a real world result that is implausible given the normative interests at stake, formalism respects the value of order in our public adminstration: "[E]xpress adherence to a well-understood formal rule of law gives voice to our aspirations for control and accountability as part of justice."119 Even if Justice Scalia's policy objections to independent counsel have merit, they are not so weighty as to overcome the burdens of text and history in divining Congress's powers over government organization. ${ }^{120}$

118. Olson illustrates the point. The targeting of former Assistant Attorney General Theodore B. Olson (for whom this author worked for several months in the Justice Department Office of Legal Counsel) for an independent investigation seems to have damaged neither Mr. Olson's reputation nor the political standing of the administration. Mr. Olson never faced allegations of misconduct other than the allegations surrounding his handling of an executive privilege dispute. He was never the subject of widespread negative publicity. It is doubtful that his name reached "household word" status because of his case. For a sympathetic account of the Olson case, see Frankel, Ted Olson's Five Years in Purgatory, Am. LAw., Dec. 1988, at 68.

By contrast, independent investigations of Attorney General Meese may have eroded political support for the administration. Mr. Meese was the subject of a wide range of allegations of misconduct; the allegations went strongly to his character, he was repeatedly the subject of negative publicity (extending beyond the purview of the independent counsel's investigation), and the independent counsel's report (and a subsequent Justice Department report) were largely critical of his conduct.

119. Shane, Conventionalism in Constitutional Interpretation and the Place of Administrative Agencies, 36 AM. U.L. REV. 573, 598 (1987).

120. For a more extended discussion of the place of textualist argument in a process of constitutional interpretation that cannot always be textualist, see generally id. 
The last Supreme Court separation of powers opinion to be issued during the Reagan years is Mistretta v. United States. 121 Over Justice Scalia's lone dissent, the Court upheld the constitutionality of the structure of the United States Sentencing Commission, an "independent commission in the judicial branch of the United States" made up of seven members, at least three of whom must be federal judges. ${ }^{122}$ All members are appointed by the President with the advice and consent of the Senate; none may be removed except "for neglect of duty or malfeasance in office or for other good cause shown." 123

The Reagan administration defended the constitutionality of the agency against the particular challenge proffered, namely, that the use of judges as commission members impermissibly extended presidential influence over the judiciary and impermissibly aggrandized judicial power. The Solicitor General argued, however, that Congress's decision to place the Commission in the judicial branch did not properly signify the nature of its function. An agency with its administrative powers, he argued, could be regarded only as "executive."124

The Supreme Court's refusal to insist that the Commission be "in" the executive branch is perhaps the most telling blow to the categorical approach to separation of powers law championed by Justice Scalia and by the administration. The Court announced the following principle: "Congress may delegate to the Judicial Branch nonadjudicatory functions that do not trench upon the prerogatives of another Branch and that are appropriate to the central mission of the Judiciary."125 The Court's holding necessarily implies that the Commission does not trench upon an executive prerogative to supervise policymaking by all administrators to whom Congress delegates authority to help implement the public law of the United States. The reason is that no such prerogative exists.

It follows from Mistretta, as from constitutional text and history, that Congress may or may not grant the President supervisory authority over administrative policymaking outside his constitutionally vested jurisdiction. Our fundamental law leaves that discretionary choice to Congress. Commentators may muster weighty policy arguments for and against agency policy independence. These are arguments, however, to be addressed to Congress, not to courts.

121. I09 S. Ct. 647 (1989).

122. 28 U.S.C. $\$ 991$ (a) (Supp. IV 1986).

123. Id.

124. Arguments Before the Court, 57 U.S.L.W. 3271, 3272-73 (U.S. Oct. 18, 1988).

125. Mistretta, $109 \mathrm{~S}$. Ct. at 663. 